\title{
Pengaruh Konsentrasi Ekstrak Nanas (Ananas Comosus) Dan Waktu Fermentasi Pada Pembuatan Nata De Coco Dari Limbah Air Kelapa
}

\author{
Mulia Aria Suzanni ${ }^{1 *}$, Aris Munandar ${ }^{2}$, Saudah $^{3}$ \\ ${ }^{1,2}$ Akademi Analis Farmasi dan Makanan Harapan Bangsa Darussalam - Banda Aceh \\ ${ }^{3}$ Fakultas Keguruan Ilmu Pendidikan Universitas Serambi Mekah - Banda Aceh \\ *Koresponden email: aria.suzanni@gmail .com
}

Diterima : 27 Februari 2020

Disetujui: 17 Maret 2020

\begin{abstract}
Coconut water waste discharged into the environment is one of the problems in traditional markets. Coconut water waste treatment can be done simply by making nata de coco using the starter of bacteria Acetobacter xylinum obtained from pineapple extracts. The research is aimed to study the effect of the concentration of pineapple extract (Ananas comosus) and fermentation time in making nata de coco from coconut water waste by experimental methods. The results of nata de coco can be seen from the maximum thickness level obtained by $1.4 \mathrm{~cm}$ at a starter concentration of $150 \mathrm{ml}$, $200 \mathrm{ml}$, and $250 \mathrm{ml}$ with a fermentation time of 21 days. The best quality of nata de coco is at $200 \mathrm{ml}$ and $250 \mathrm{ml}$ starter concentrations witch a content water of $13.79 \%$ and mineral content of $0.175 \%$. The high percentage of nata de coco favorite level is the $250 \mathrm{ml}$ starter concentration, based on the level of preference for color, shape, aroma, taste, and suppleness.
\end{abstract}

Keywords: Coconut water, pineapple extract, nata de coco

\begin{abstract}
Abstrak
Limbah air kelapa yang dibuang ke lingkungan menjadi salah satu masalah di pasar-pasar tradisional. Air limbah kelapa dapat diolah secara sederhana menjadi nata de coco menggunakan starter bakteri Acetobacter xylinum yang diperoleh dari ekstrak nanas. Tujuan penelitian ini adalah untuk melihat pengaruh konsentrasi ekstrak nanas (Ananas comosus) dan waktu fermentasi pada Nata de coco limbah air kelapa dengan metode eksperimental. Hasil Nata de coco dilihat dari tingkat ketebalan yang maksimal diperoleh $1,4 \mathrm{~cm}$ pada konsentrasi starter $150 \mathrm{ml}, 200 \mathrm{ml}$ dan $250 \mathrm{ml}$ dengan waktu fermentasi 21 hari. Kualitas Nata de coco terbaik adalah pada konsentrasi starter 200 $\mathrm{ml}$ dan $250 \mathrm{ml}$ dengan kadar air 13,79\% dan kadar mineral sebesar0.175\%. Persentase tingkat kesukaan Nata de coco yang tinggi yaitu pada konsentrasi starter $250 \mathrm{ml}$, berdasarkan tingkat kesukaan terhadap warna, bentuk, aroma, rasa, dan kekenyalan.
\end{abstract}

Kata kunci: Air kelapa, ekstrak nanas, nata de coco

\section{Pendahuluan}

Indonesia merupakan penghasil komoditi terbanyak disektor perkebunan, contohnya adalah kelapa (Cocus nucifera). Pemanfaatan kelapa di dunia industri sanngat banyak [1]. Bagian kelapa yang dapat dimanfaatkan adalah seperti bagian daun, akar, batang sampai buah. Daun keringnya dimanfaatkan sebagai atap rumah, daun muda (janur) dimanfaatkan untuk membuat ata lainnya, buah kelapa muda dapat dikosumsi langsung dan mengandung nilai gizi tinggi, buah kelapa tua memiliki menghasilkan sari yaitu santan dan daging keras yang dikeringkan dapat difermentasi menjadi kopra yaitu bahan baku penghasil minyak kelapa [2]. Air kelapa tua biasanya tidak banyak dijadikan sebagai minuman penyegar, sehingga produksi air kelapa cukup melimpah yaitu mencapai \pm 900 juta liter per tahun [3]. Menurut ref. [4] air kelapa yang terbuang dapat menimbulkan masalah lingkungan yaitu polusi udara (bau) akibat aromanya setelah dibuang ke lingkungan dalam waktu tertentu. Limbah air kelapa setiap harinya meningkat lebih besar bila dibandingkan dengan jumlah yang dimanfaatkan. Strategi yang dapat dilakukan adalah mengolah limbah air kelapa secara sederhana melalui pembuatan nata de coco.

Nata de coco adalah produk makanan yang mengandung serat selulosa tinggi yang baik untuk melancarkan pencernaan [5]. Nata de coco berbentuk padat, kenyal, putih dan transparan dengan rasa 
dan tekstur yang lembut. Nata de coco banyak digunakan sebagai pencampur dalam makanan dan minuman seperti es krim, coktail buah, sirup dan lain-lain. Kandungan kalorinya yang rendah, sangat tepat dikonsumsi sebagai makanan diet [6]. Kandungan Nata de coco lainnya adalah vitamin B (B1 dan B2) serta vitamin C [7]. Acetobacter xylinum adalah bakteri yang berperan dalam proses pembuatan nata de coco dengan beberapa komponen media untuk pertumbuhannya, seperti sumber karbon, nitrogen, mineral, dan vitamin. penggunaan gula dalam proses pembuatannya berfungsi sebagai sumber karbon dan sumber nitrogen dapat diperoleh dari penambahan urea, sedangkan sumber vitamin dan mineral dapat diperoleh dari air kelapa itu sendiri [8].

Kegunaan utama Acetobacter xylinum digunakan disegala bidang bioteknologi yang menghasilkan nata, salah satunya nata de coco [9]. Namun dalam penelitian ini penggunaan bakteri ini dapat digantikan dengan ekstrak buah nanas (Ananas comosus). Fermentasi ekstak buah nanas yang dapat menghasilkan Acetobacter xylinum mampu menghasilkan serat sebagai nata [10]. Penggunaan buah nanas sebagai stater dalam pembuatan nata de coco dari air kelapa diharapkan dapat memaksimalkan produksi nata yang dihasilkan, selain itu pembuatan nata dari air kelapa diharapkan dapat mengurangi permasalahan limbah air kelapa sehingga mampu mengurangi polusi limbah air kelapa. Hasil penelitian ini nantinya diharapkan dapat meningkatkan nilai produk olahan air kelapa dan dapat diaplikasikan pada masyarakat untuk meningkatkan income dan meningkatkan perekonomian masyarakat dengan membuka usaha pembuatan nata de coco, mengingat nata de coco adalah jenis produk pangan yang banyak digemari dalam penggunaannya di masyarakat.

\section{Metode Penelitian}

Penelitian ini dilaksanakan di Laboratorium Analisis Farmasi dan Makanan Banda Aceh, AKAFARMA dari bulan Agustus sampai September 2019.

\section{Penyiapan starter}

Buah nanas dibersihkan, dikupas dan selanjutnya diblender. selanjutnya nanas diperas dan diambil ampasnya. Ampas nanas kemudian ditambahkan gula dan air dengan perbandingan 2:1:1 (nanas:gula:air). Campuran tersebut disimpan ke dalam toples kaca dan diinkubasi selama 7 hari (pada suhu ruang). Cairan yang dihasilkan dijadikan sebagai starter dalam pembuatan nata [11].

\section{Pembuatan nata de coco}

air kelapa mentah sebanyak Lima (5) liter disaring dan dimasak sampai mendidih $\left(100^{\circ} \mathrm{C}\right)$. ditambahan $250 \mathrm{~g}$ gula pasir, $40 \mathrm{ml}$ cuka, dan $10 \mathrm{sdm}$ ekstrak tauge. dipanaskan kembali sampai 10 menit, setelah dingin kemudian dimasukkan ke dalam wadah plastik yang bersih atau steril. Kemudian ditutup dengan kertas koran steril dan penutup dikencangkan dengan karet atau tali, ditunggu hingga dingin. Ditambah starter dengan konsentrasi berbeda $(50 \mathrm{ml}, 100 \mathrm{ml}, 150 \mathrm{ml}, 200$ $\mathrm{ml}$, dan $250 \mathrm{ml}$ ). Selanjutnya wadah tersebut ditutup kembali dengan plastik warp dan dilapisi koran. wadah ini tidak boleh terganggu atau tergoyang. Selanjutnya diinkubasi (proses fermentasi) pada suhu ruang. Pengaruh fermentasi terhadap pembentukan nata de coco dilihat pada hari ke 6, 11, 16, dan 21. Diukur ketebalan nata de coco tersebut [10]

Karakteristik Nata Decoco

\section{Uji Organoleptik dan Penetapan Kadar Air [12]}

Dilakukan dengan parameter pengujian berdasarkan warna, bentuk, dan bau terhadap nata de coco yang dihasilkan. Penetapan kadar air menggunakan metode gravimetri secara oven. Pertama ditimbang wadah kosong, kemudian ditimbang sampel sebanyak 2-3 g yang sudah dihaluskan. Kemudian dimasukkan dalam oven pada suhu $105^{\circ} \mathrm{C}$ selama 3-5 jam, lalu dimasukkan ke desikator. Sampel ditimbang secara berulang hingga diperoleh bobot tetap.

\section{Penetapan Kadar Mineral dan Uji kesukaan}

Ditimbang wadah kosong, ditimbang sampel sebanyak 5 gr yang sudah dihaluskan, diabukan (dibakar) dalam tanur listrik pada suhu maksimum $500^{\circ} \mathrm{C}$. Sampel didinginkan dalam desikator lalu timbang sampai bobotnya tetap, tidak berubah lagi. Pengujian parameter berdasarkan warna, bentuk, bau dan rasa dilakukan dengan melibatkan 10 orang panelis. Tingkat kesukaan dihitung dalam persentase terhadap total panelis.

\section{Hasil dan Pembahasan}

Starter adalah biakan mikroba tertentu yang ditumbuhkan di dalam substrat atau medium yang akan digunakan dalam proses tertentu. Pada penelitian ini buah nanas dimanfaatkan sebagai media starter untuk memperoleh starter bakteri Acetobacter xynilum yang akan digunakan dalam proses pembuatan nata de coco. Secara alami pada nanas telah ada bakteri Acetobacter xylinum dengan 
jumlah yang sedikit. Proses pembuatan starter menggunakan daging nanas, yang dihaluskan kemudian disaring untuk dapat diambil ampasnya. Ampas yang digunakan ditambahkan gula dan air dengan perbandingan (2:1:1). Penambahan gula dimaksudkan sebagai penambah nutrisi bagi bakteri Acetobacter xylinum selama proses fermentasi [11]. Kemudian diinkubasi dalam suhu ruang selama satu minggu, hingga diperoleh starter yang maksimal (Gambar 1).

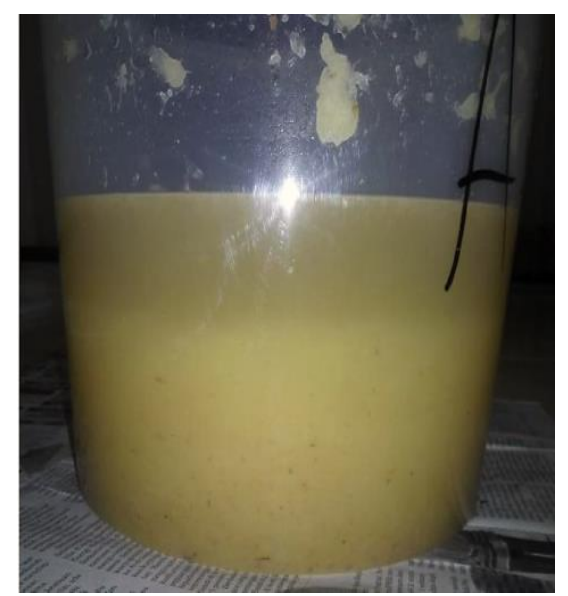

Gambar 1. Starter ekstrak nanas

Sumber: Hasil penelitian, 2019

Gambar 1 menunjukkan starter nanas yang dihasilkan berwarna kuning pudar dan larutannya kental. Starter nanas ini juga berbau asam. Hal ini menunjukkan adanya pertumbuhan bakteri Acetobacter xynilum yang tumbuh dengan baik. Berdasarkan hal tersebut, ekstrak nanas baik digunakan sebagai media pertumbuhan bagi bakteri tersebut. Beberapa penelitian lain menunjukkan penambahan ekstrak nanas sebagai stater juga dapat membentuk nata dengan ketebalan yang baik. Stater dapat diperoleh dari daging buah, bonggol dan kulit buah nanas. Hasil penelitian [13] menunjukkan stater yang diperoleh dari bonggol nanas menghasilkan nata yang lebih baik dan tebal $(1,5 \mathrm{~cm})$ dibanding menggunakan kulit $(1,4 \mathrm{~cm})$ dan dagingnya $(1,3 \mathrm{~cm})$ dengan penambahan volume stater yang sama $(120 \mathrm{~mL})$ dan substrat air kelapa $(1,5 \mathrm{~L})$ dengan waktu fermentasi 7 hari. Sedangkan dalam penelitian lainnya [14] hanya menggunakan nanas (bertindak sebagai substrat langsung) untuk menghasilkan nata tanpa subtrat air kelapa yang dikenal dengan nata depina. Hasil menunjukkan bagian kulit nanas menghasilkan nata yang lebih baik dibanding bagian bonggol dan daging buahnya. Pemanfaatan buah nanas sebagai stater dalam pembuatan nata de coco dianggap sangat baik untuk menghasilkan bakteri Acetobacter xynilum yang berperan dalam pembentukan selulosa (nata).

\section{Pembuatan Nata De Coco}

Aktivitas Acetobacter xynilum mempunyai peran penting dalam pembutan nata de coco dalam mengubah glukosa menjadi membran selulosa [10]. Pembuatan nata menggunakan air kelapa yang tua dengan penambahan komponen lainnya untuk media nata seperti sumber karbon, nitrogen, mineral, dan vitamin. Sumber karbon dapat diperoleh dari gula dan sumber nitrogen dapat diperoleh dari ekstrak tauge, sedangkan mineral dan vitamin bersumber dari air kelapa itu sendiri [13][16]. Pengotor atau residu dalam air kelapa terlebih dahulu disaring agar hilang. Selanjutnya air kelapa dipanaskan sampai mendidih agar bakteri kontaminan tidak mengganggu proses berikutnya, sehingga diharapkan hanya bakteri Acetobacter xylinum yang tumbuh dalam media pembuatan nata de coco tersebut. Selain itu pemanasan ini juga berfungsi untuk menghidrolisis karbohidrat menjadi gula sederhana, sehingga mempercepat proses pembentukan selulosa oleh bakteri Acetobacter xylinum. Penambahan starter Acetobacter xynilum dengan konsentrasi berbeda dapat mempengaruhi tingkat ketebalan nata yang dibentuk pada waktu fermentasi. Pengaruh penambahan starter dan waktu fermentasi dalam pembuatan nata de coco dapat di lihat pada Tabel 1. 
Tabel 1. Tingkat ketebalan nata de coco dari air kelapa terhadap konsentrasi starter ekstrak nanas yang berbeda.

\begin{tabular}{ccccc}
\hline Konsentrasi Strarter & \multicolumn{4}{c}{ Waktu pengamatan (Hari) } \\
\cline { 2 - 5 } Ekstrak Nanas & 6 & 11 & 16 & 21 \\
\hline $50 \mathrm{ml}$ & $0,3 \mathrm{~cm}$ & $0,8 \mathrm{~cm}$ & $1 \mathrm{~cm}$ & $1 \mathrm{~cm}$ \\
$100 \mathrm{ml}$ & $0,4 \mathrm{~cm}$ & $1 \mathrm{~cm}$ & $1,2 \mathrm{~cm}$ & $1,3 \mathrm{~cm}$ \\
$150 \mathrm{ml}$ & $0,4 \mathrm{~cm}$ & $1 \mathrm{~cm}$ & $1,3 \mathrm{~cm}$ & $1,4 \mathrm{~cm}$ \\
$200 \mathrm{ml}$ & $0,4 \mathrm{~cm}$ & $1,1 \mathrm{~cm}$ & $1,3 \mathrm{~cm}$ & $1,4 \mathrm{~cm}$ \\
$250 \mathrm{ml}$ & $0,4 \mathrm{~cm}$ & $1,1 \mathrm{~cm}$ & $1,3 \mathrm{~cm}$ & $1,4 \mathrm{~cm}$ \\
\hline
\end{tabular}

Sumber: Hasil penelitian, 2019

Pengaruh konsentrasi dari setiap starter terhadap tingkat ketebalan nata de coco dengan perbedaan hari tertentu mengalami tingkat ketebalan yang stabil, kecuali starter ekstrak nanas pada konsentrasi $50 \mathrm{ml}$ yang memiliki laju pembentukan nata yang lambat, dilihat dari ketebalan nata de coco yang terbentuk selama perlakuan (21 hari). Hal ini dikarenakan konsentrasi starter nanas yang kecil, sehingga jumlah bakteri untuk mengubah polisakarida menjadi selulosa tidak maksimal. Selain starter sebagai faktor utama, faktor lain juga mempengaruhi terbentuknya nata yang baik yaitu nutrisi, suhu serta tingkat keasaman. Nutrisi diperoleh dari penambahan gula, ekstrak tauge, dan cuka. Penambahan gula pasir ke dalam air kelapa dimaksudkan untuk memenuhi kebutuhan karbon bagi bakteri Acetobacter xylinum. Ekstrak tauge ditambahkan sebagai sumber nitrogen, namun sumber ini tidak mutlak diperlukan karena nitrogen dapat diasimilasi dari protein yang terkandung dalam air kelapa [17].

Namun penambahan tauge dalam penelitian ini diharapkan dapat mempercepat laju pembentukan nata dengan adanya sumber nitrogen bagi bakteri Acetobacter xylinum. Tingkat keasaman juga berpengaruh terhadap pembentukan nata de coco. Untuk meningkatkan keasaman ditambahkan cuka sampai $\mathrm{pH} 4$ supaya tingkat keasaman dapat terjaga dengan baik sehingga bakteri Acetobacter xylinum mampu menghasilkan nata de coco secara maksimal. Pembentukan nata de coco yang baik dihasilkan pada konsentrasi $150 \mathrm{ml}$, hal ini dikarenakan jumlah volume substrat dan konsentrasi starter yang seimbang mampu menghasilkan nata de coco dengan ketebalan yang 1,4 cm. Menurut [18] nata de coco dengan ketebalan bagus yaitu antara 1 sampai dengan 1,5 cm, ketebalan ini tidak jauh beda dari nata de coco yang dihasilkan dengan konsentrasi ekstrak nanas yang berbeda.

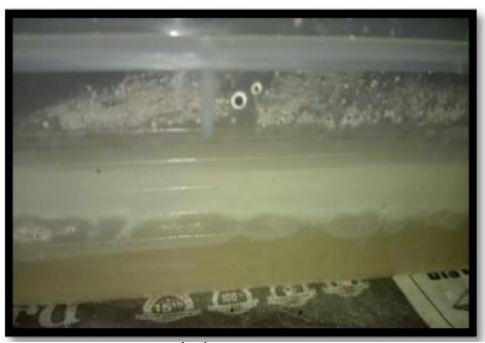

(a)

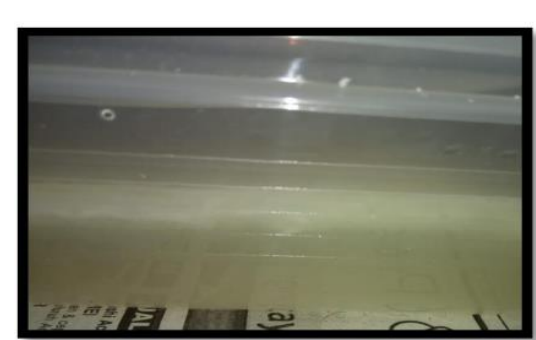

(d)

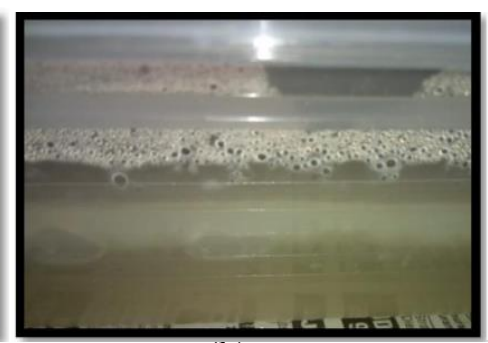

(b)

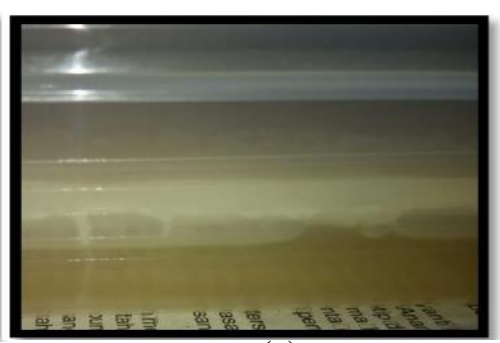

(c)

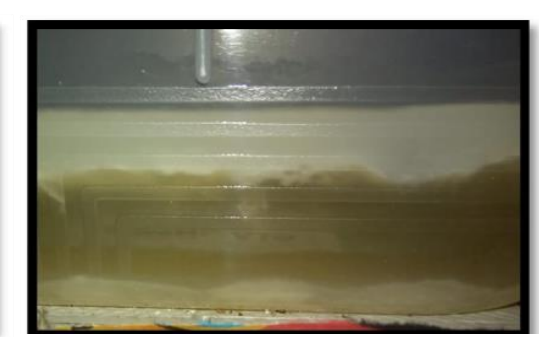

(e)

Gambar 2. Nata de coco pada hari ke 21 dengan konsentasi ekstrak nanas: (a) $50 \mathrm{ml}$, (b) $100 \mathrm{ml}$, (c) $150 \mathrm{ml}$, (d) $200 \mathrm{ml}$ dan (e) $250 \mathrm{ml}$.

Sumber: Hasil penelitian, 2019

Suatu produk makanan maupun minuman yang diproduksi harus mempunyai kualitas yang baik. Produk nata de coco yang di hasilkan dalam penelitian ini dilihat kualitasnya dengan melakukan penentuan kadar air, penentuan kadar mineral, dan uji organoleptik. 


\section{Kadar Air}

Untuk menentukan kadar air dilakukan dengan menggunakan oven, berdasarkan pada selisih berat sebelum pemanasan dan sesudah pemanasan yang dilakukan pada suhu $105^{\circ} \mathrm{C}$ selama 240 menit. Suhu tersebut digunakan agar air yang terdapat dalam nata dapat menguap secara maksimal. Jika suhu yang digunakan terlalu tinggi maka bahan akan mengalami pengerasan pada bagian permukaan luar namun pada bagian dalam bahan tersebut masih belum matang atau lunak sehingga air dalam bahan masih terperangkap di dalamnya [19]. Hasil kadar air nata de coco dengan konsentrasi berbeda terlihat pada Tabel 2.

Tabel 2. Kadar air nata de coco dari air kelapa pada konsentrasi starter ekstrak nanas yang berbeda

\begin{tabular}{ccccc}
\hline $\begin{array}{c}\text { Konsentrasi Strarter } \\
\text { Ekstrak Nanas }\end{array}$ & I & II & II & $\begin{array}{c}\text { Kadar Air } \\
(\%)\end{array}$ \\
\cline { 2 - 4 } & 2,131 & 2,131 & 2,130 & 32,34 \\
$100 \mathrm{ml}$ & 2,438 & 2,438 & 2,438 & 20,37 \\
$150 \mathrm{ml}$ & 2,515 & 2,515 & 2,514 & 18,58 \\
$200 \mathrm{ml}$ & 2,655 & 2,654 & 2,653 & 13,79 \\
$250 \mathrm{ml}$ & 2,614 & 2,614 & 2,614 & 13,79 \\
\hline
\end{tabular}

Sumber: Hasil penelitian, 2019

Kadar air yang paling tinggi terlihat pada konsentrasi starter $50 \mathrm{ml}$ yaitu 32,34 \%, dengan ketebalan nata de coco $1 \mathrm{~cm}$. Sedangkan kadar air yang paling rendah yaitu pada konsentrasi stater nanas $200 \mathrm{ml}$ dan $250 \mathrm{ml}$ yaitu 13,79\%, dengan ketebalan nata de coco 1,4 cm. Tinggginya kadar air pada nata de coco diduga dipengaruhi oleh tingkat ketebalan dan kekenyalan dari nata de coco tersebut. Nata dengan konsentrasi starter $50 \mathrm{ml}$, memiliki ketebalan nata kecil dibandingkan yang lainnya dan bertekstur lunak, sehingga di duga kadar airnya masih tinggi. Sedangkan pada nata de coco yang konsentrasi starter nanas $200 \mathrm{ml}$ dan $250 \mathrm{ml}$ tingkat ketebalannya lebih besar dibandingkan yang lain dan tingkat kekenyalan juga lebih baik (lebih kenyal dari nata yang lain), hal ini dilihat berdasarkan tingkat kesukaan (Tabel 5). Tingkat kekenyalan dapat mempengaruhi kadar air dari nata, semakin kenyal nata de coco maka kadar airnya akan semakin kecil juga.

Apabila Bakteri Acetobacter xylinum ditambahkan pada medium gula, maka akan membentuk polisakarida yaitu selulosa ekstraselluler dan mengalami oksidasi lanjutan dengan mengoksidasi asam asetat menjadi $\mathrm{CO}_{2}$ dan $\mathrm{H}_{2} \mathrm{O}$, sehingga jika penambahan gula semakin tinggi maka akan semakin rendah kadar air yang dihasilkan [16]. Pada tabel 2 dapat dilihat bahwasanya menggunakan konsentrasi starter berbeda menunjukkan kadar air nata de coco berbeda antara konsentrasi satu dengan lainnya. Hal ini diduga dipengaruhi oleh tingkat ketebalan nata yang terbentuk dan tingkat kekenyalan dari nata tersebut.

\section{Kadar Mineral}

Kadar abu (kadar mineral) merupakan campuran komponen anorganik atau mineral yang terdapat pada suatu bahan pangan. Umumnya bahan pangan mengandung 96\% bahan anorganik dan air, sedangkan sisanya merupakan unsur-unsur mineral dikenal sebagai zat anorganik atau kadar abu. Kadar abu tersebut dapat menunjukan total mineral dalam suatu bahan pangan. Sedangkan bahan-bahan organik dalam proses pembakaran akan hilang (terbakar) tetapi komponen anorganiknya tidak [20]. Prinsip penentuan kadar abu (mineral) adalah dengan mengkondisikan semua zat organik pada suhu yang tinggi, yaitu sekitar $500-600^{\circ} \mathrm{C}$, kemudian ditimbang zat hasil pembakaran yang tertinggal. Hasil penentuan mineral dalam nata de coco dapat dilihat pada Tabel 3.

Tabel 3. Kadar mineral nata de coco dari air kelapa pada konsentrasi starter ekstrak nanas yang berbeda

\begin{tabular}{ccccc}
\hline Konsentrasi Strarter & \multicolumn{3}{c}{ Penimbangan (g) } & \multirow{2}{*}{ Kadar Mineral } \\
Ekstrak Nanas & I & II & III & 0,077 \\
\cline { 2 - 4 } $50 \mathrm{ml}$ & 0,005 & 0,004 & 0,004 & 0,095 \\
$100 \mathrm{ml}$ & 0,005 & 0,005 & 0,005 & 0,095 \\
$150 \mathrm{ml}$ & 0,006 & 0,005 & 0,005 & 0,174 \\
$200 \mathrm{ml}$ & 0,01 & 0,009 & 0,009 & 0,175 \\
$250 \mathrm{ml}$ & 0,009 & 0,009 & 0,009 & \\
\hline
\end{tabular}

Sumber: Hasil penelitian, 2019

Kadar mineral dari nata de coco dari kelima konsentrasi berbeda menunjukkan kadar yang berbeda, hal ini dikarenakan pengaruh ketebalan nata terhadap kadar abu yang di hasilkan. Kadar mineral tertinggi terlihat pada konsentrasi starter $200 \mathrm{ml}$ dan $250 \mathrm{ml}$ yaitu masing masing 0,174 dan 
$0,175 \%$ dengan ketebalan nata $1,4 \mathrm{~cm}$. Sedangkan kadar mineral yang paling rendah yaitu pada konsentrasi starter $50 \mathrm{ml}$ yaitu $0,077 \%$ dengan ketebalan nata $1 \mathrm{~cm}$.

\section{Organoleptik}

Pengujian organoleptik dilakukan untuk melihat tingkat kesukaan produk nata de coco yang di dihasilkan. Tingkat kesukaan dilihat terhadap warna, bentuk, aroma, rasa dan kekenyalan dengan melibatkan panelis sebagai penguji, dengan ketentuan panelis sebagai penikmat nata de coco dengan rantang usia 20 sampai dengan 30 tahun. Persentase tingkat kesukaan panelis dapat dilihat pada Tabel 4.

Tabel 4. Tingkat kesukaan panelis terhadap nata de coco dari limbah air kelapa dengan konsentrasi starter ekstrak nanas yang berbeda

\begin{tabular}{cccccc}
\hline Konsentrasi Starter & \multicolumn{5}{c}{ Tingkat kesukaan (\%) } \\
\cline { 2 - 6 } Ekstrak Nanas & Warna & Bentuk & Aroma & Rasa & Kekenyalan \\
\hline $50 \mathrm{ml}$ & 80 & 20 & 60 & 80 & 10 \\
$100 \mathrm{ml}$ & 95 & 50 & 60 & 50 & 60 \\
$150 \mathrm{ml}$ & 100 & 100 & 50 & 80 & 80 \\
$200 \mathrm{ml}$ & 100 & 100 & 80 & 80 & 90 \\
$250 \mathrm{ml}$ & 100 & 100 & 100 & 100 & 90 \\
\hline
\end{tabular}

Sumber: Hasil penelitian, 2019

Hasil tingkat kesukaan pengujian organoleptik yang paling menonjol terlihat pada konsentrasi starter $250 \mathrm{ml}$, dimana panelis lebih suka nata de coco dengan konsentrasi starter tinggi daripada konsentari starter yang rendah. Pada konsentrasi starter $250 \mathrm{ml}$ nata yang dihasilkan memiliki karakteristik lebih banyak disukai berdasarkan warna, bentuk, aroma, rasa, dan kekenyalan (Tabel 5). Karakteristik yang sangat berpengaruh terhadap kesukaan panelis adalah tingkat kekenyalan dan rasa. Nata yang disukai memiliki warna putih, berbentuk dadu, aroma yang netral, dengan rasa hambar, dan tingkat kekenyalan yang sangat baik. Nata yang kurang disukai memiliki warna putih keruh, berbentuk dadu, aroma yang asam, dengan rasa asam dan tingkat kekenyalan yang kurang. Saat ini nata banyak diproduksi dari air kelapa. Produk nata yang banyak beredar dipasaran adalah jenis minuman dalam kemasan.

Tabel 5. Pengamatan karakteristik nata de coco

\begin{tabular}{cccccc}
\hline Konsentrasi & \multicolumn{5}{c}{ Pengamatan karakteristik } \\
\cline { 2 - 6 } starter & Warna & Bentuk & Aroma & Rasa & Kekenyalan \\
\hline $50 \mathrm{ml}$ & Putih keruh & Dadu & Asam & Asam & Kurang \\
$100 \mathrm{ml}$ & Putih keruh & Dadu & Asam & Asam & Kurang \\
$150 \mathrm{ml}$ & Putih & Dadu & Sedikit asam & Sedikit asam & Baik \\
$200 \mathrm{ml}$ & Putih & Dadu & Sedikit asam & Hambar & Baik \\
$250 \mathrm{ml}$ & putih & Dadu & Normal & Hambar & Sangat baik \\
\hline & & Sumber: Hasil penelitian, 2019 &
\end{tabular}

\section{Kesimpulan}

Berdasarkan hasil penelitian, dapat disimpulkan bahwa ekstrak nanas dapat digunakan sebagai starter dalam pembuatan nata de coco secara maksimal. Konsentrasi starter dan waktu fermentasi dapat mempengaruhi ketebalan nata yang terbentuk. Konsentrasi starter nanas pada $150 \mathrm{ml}$ memiliki katebalan nata yang lebih baik, namun memiliki tingkat kekenyalan yang rendah. Sedangkan konsentrasi starter nanas pada $200 \mathrm{ml}$ dan $250 \mathrm{ml}$ memiliki kekenyalan yang lebih baik dibandingkan dengan konsentrasi lainnya. Ketebalan dan kekenyalan nata dapat mempengaruhi kadar air dan kadar mineral dari nata de coco. Nata pada konsentrasi starter $250 \mathrm{ml}$ memiliki tingkat kesukaan yang paling tinggi dibandingkan yang lain, dilihat dari warna, bentuk, aroma, rasa, dan kekenyalan.

\section{Referensi}

[1] Suryani E, Farid M and Mayub A, "Implementasi Karakteristik Nilai Kalor Briket Campuran Limbah Kulit Durian dan Tempurung Kelapa pada Pembelajaran Suhu dan Kalor Di SMP N 15 Kota Bengkulu,” PENDIPA J. Sci. Educ, 2019.

[2] Renjaan M J, Purnaweni H and Anggoro D D, "Studi Kearifan Lokal Sasi Kelapa Pada Masyarakat Adat Di Desa Ngilngof Kabupaten Maluku Tenggara,” J. Ilmu Lingkungan, 2013. 
[3] Barlina R and Barlina R B P T K dan P L, Potensi Buah Kelapa Muda Untuk Kesehatan dan Pengolahannya Perspektif, 2016.

[4] Djajanegara I, "Pemanfaatan Limbah Buah Pisang Dan Air Kelapa Sebagai Bahan Media Kultur Jaringan Anggrek Bulan (Phalaenopsis amabilis) TIPE 229," J. Teknol. Lingkung, 2016.

[5] Gresinta E, Pratiwi R D, Damayanti F and Putra E P, "Komparasi Yield Nata De Tomato Dengan Nata De Coco Berdasarkan Lama Fermentasi,” IJIS Edu Indones. J. Integr. Sci. Educ, 2019.

[6] Almatsier S, Ilmu gizi dasar, PT Gramedia Pustaka Utama, Jakarta, 2009.

[7] Kristianingrum S, Kandungan gizi nata de coco 1-8, 2004.

[8] Nurdyansyah F and Widyastuti D A, "Pengolahan Limbah Air Kelapa Menjadi Nata De Coco oleh Ibu Kelompok Tani Di Kabupaten Kudus," J. Kewirausahaan dan Bisnis, 2017.

[9] Hirai A, Tsujii Y, Tsuji M and Horii F, Acetobacter xylinum Biomacromolecules, 2004.

[10] Majesty J, Argo B D and Nugroho W A, "Pengaruh Penambahan Sukrosa dan Lama Fermentasi Terhadap Kadar Serat Nata dari Sari Nanas (Nata de Pina)," J. Keteknikan Pertan. Trop. dan Biosist, 2015.

[11] Ferdiansyah M K, Supriyadi B, Affandi A R and Muflihati I, "Pemberdayaan Ekonomi Ibu Rumah Tangga Kelurahan Banyumanik Kecamatan Banyumanik Kota Semarang melalui Pembuatan Sirup Herbal,” LOGISTA - J. Ilm. Pengabdi. Kpd. Masy, 2018.

[12] Sihmawati R, "Aspek Mutu Produk Nata De Coco Dengan Penambahan Sari Buah Mangga," J. Tek. Ind. HEURISTIS, 2014.

[13] Ramadhan B R, Rangkuti M E, Safitri S I, Apriani V, Raharjo A S, Titisgati E A and Afifah D N, "Pengaruh Penggunaan Jenis Sumber Gula Dan Urea Terhadap Hasil Fermentasi Nata De Pina," $J$. Nutr. Coll, 2019.

[14] Edria D and Wibowo M, "Pengaruh Penambahan Kadar Gula dan Kadar Nitrogen terhadap Ketebalan, Tekstur, dan Warna Nata de Coco," J. Ilmu dan Teknol. Pangan, 2010.

[15] Salafudin, Pratama Y and Malviane E, "Fermentasi Sampah Buah Nanas menggunakan Sistem Kontinu dengan bantuan Bakteri Acetobacter Xylinum," J. Inst. Teknol. Nas, 2014.

[16] Putriana I and Aminah S, "Mutu Fisik, Kadar Serat dan Sifat Organoleptik Nata de Cassava Berdasarkan Lama Fermentasi," J. Pangan dan Gizi, 2013.

[17] Andriani A F, "Viabilitas Dan Produktivitas Selulosa Dari Inokulum Kering Acetobacter xylinum Dengan Substrat Pembawa Berupa Serbuk Kelapa Parut Dan Serbuk Ampas Kelapa Parut," elHayah, 2012.

[18] A R T, Chairunnissa H and Balia R L, "Karakteristik Fisik Dan Kimia Nata De Milko Dari Susu Substandar Dengan Variasi Lama Inkubasi," J. Ilmu Ternak Univ. Padjadjaran, 2019. 